\title{
Tekstil Endüstrisi Atıksularının Sonlu Filtrasyon Sistemi ile Nanofiltrasyon ve Ters Ozmoz Membranları Kullanılarak Filtrasyonu
}

\author{
Adem YURTSEVER ${ }^{1,2 *}$, Deniz UÇAR ${ }^{3}$, Erkan ŞAHINKAYA ${ }^{4}$ \\ ${ }^{I}$ İnşaat Mühendisliği Bölümü, Mühendislik Fakültesi, Hasan Kalyoncu Üniversitesi, Gaziantep \\ ${ }^{2}$ Çevre Uygulama ve Araştırma Merkezi, Hasan Kalyoncu Üniversitesi, Gaziantep \\ ${ }^{3}$ Çevre Mühendisliği Bölümü, Mühendislik Fakültesi, Harran Üniversitesi, Sanlıurfa \\ ${ }^{4}$ Biyomühendislik Bölümü, Mühendislik ve Doğa Bilimleri Fakültesi, İstanbul Medeniyet Üniversitesi, İstanbul \\ (ORCID: 0000-0001-6512-5232) (ORCID: 0000-0002-0536-6250) (ORCID: 0000-0002-9898-9173)
}

\begin{abstract}
$\ddot{O} z$
Mevcut çalışmada çeşitli nanofiltrasyon (NF) ve ters ozmoz (TO) membranları ile tekstil endüstrisi atıksularının filtrasyon performansları değerlendirilmiştir. Çalışmalar sonlu filtrasyon düzeneği ile farklı basınçlar altında yapılmış̧ır $(10,15,20$ ve 25 Bar). Test edilen nanofiltrasyon membranları NF90, NF270, NFTS40, NFXN45, NFDK ve NFDL'dir. Ters ozmoz membranları ise ROX201, ROBW30FR ve ROACM5'tir. Nanofiltrasyon membranları için basınç başına en yüksek geçirgenlik NF270 membranı ile elde edilmiş olup bu değer 5,95 $\mathrm{L} /\left(\mathrm{m}^{2}\right.$.h.Bar)'tır. Diğer nanofiltrasyon membranlarına nazaran NF270 ile daha yüksek geçirgenlik değerine ulaşılmasına rağmen, geçirgenlikteki birim zamanda en yüksek azalma da bu membranda olmuştur. 15 bar basinç altında başlangıç geçirgenlik değeri olan $12,41 \mathrm{~L} /\left(\mathrm{m}^{2}\right.$.h.Bar) 1 saatlik test süresi sonunda, $4,41 \mathrm{~L} /\left(\mathrm{m}^{2}\right.$.h.Bar)'a düşmüştür. Ters ozmoz membranlarında ise en yüksek geçirgenlik değeri ROACM5 membranı ile 2,96 $\mathrm{L} /\left(\mathrm{m}^{2}\right.$.h.Bar) olarak tespit edilmiştir. En yüksek geçirgenlik düşüşü de yine ROACM5 membranında

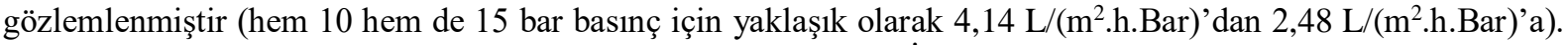
Nanofiltrasyon membranları için en yüksek renk, iletkenlik ve KOİ giderimi, NF90 ile $4515 \mu \mathrm{S} / \mathrm{cm}$ iletkenlik; 518 Pt-Co renk ve $119 \mathrm{mg} / \mathrm{L}$ KOİ giriş koşulları için sırasıyla $>95 \%,>99 \%$ ve $>97 \%$ olarak bulunmuştur. Daha yüksek iletkenlik giderimi istendiğinde ise ters ozmoz membranlarının kullanılması gerekmektedir. Test edilen ters ozmoz membranları için iletkenlik giderim yüzdeleri aynı atıksuda ROBW30FR, ROX201 ve ROACM5 için sırasıyla $>97 \%,>98 \%$ ve $>98 \%$ 'dir.
\end{abstract}

Anahtar kelimeler: Sonlu filtrasyon, nanofiltrasyon, ters ozmoz, tekstil atıksuyu, membran filtrasyonu.

\section{Filtration of Textile Industry Wastewaters Using Dead End Filtration System with Nanofiltration and Reverse Osmosis Membranes}

\begin{abstract}
In this study, filtration performance of various nanofiltration and reverse osmosis membranes and textile industry wastewater were evaluated. The work was carried out under different pressures (10-15-20 and 25 Bar) with a dead end filtration system. The nanofiltration membranes tested were NF90, NF270, NFTS40, NFXN45, NFDK and NFDL. Reverse osmosis membranes are ROX201, ROBW30FR and ROACM5. The highest permeability per pressure for nanofiltration membranes was obtained with NF270 membrane, which is $5.95 \mathrm{~L} /\left(\mathrm{m}^{2}\right.$.h.Bar). Although higher permeability was achieved with NF270 compared to other nanofiltration membranes, the highest reduction in permeability per unit time was also found in this membrane. The initial permeability value of $12.41 \mathrm{~L} /\left(\mathrm{m}^{2} . \mathrm{h} . \mathrm{Bar}\right)$ under a pressure of 15 Bar decreased to $4.41 \mathrm{~L} /\left(\mathrm{m}^{2}\right.$.h.Bar) after a 1 hour test period. In reverse osmosis membranes, the highest permeability value was determined as $2.96 \mathrm{~L} /\left(\mathrm{m}^{2}\right.$.h.Bar) by ROACM5 membrane and the highest permeability decrease was observed again in ROACM5 membrane (approximately from $4.14 \mathrm{~L} /\left(\mathrm{m}^{2}\right.$.h.Bar) to $2.48 \mathrm{~L} /\left(\mathrm{m}^{2}\right.$.h.Bar) for both 10 and 15 Bar pressures). Highest color, conductivity and COD removal for nanofiltration membranes was obtained with NF90 membranes. The influent was contained $4515 \mu \mathrm{S} / \mathrm{cm}$ conductivity; 518 Pt-Co color and $119 \mathrm{mg} / \mathrm{L}$ COD , and $>95 \%,>99 \%$ and $>97 \%$ removal efficiency were obtained, respectively. When higher conductivity removal is desired, reverse osmosis membranes are required The percent conductivity removal for the tested reverse osmosis membranes is $>97 \%,>98 \%$ and $>98 \%$ for ROBW30FR, ROX201 and ROACM5 in the same wastewater, respectively.
\end{abstract}

Keywords: Dead-end filtration, nanofiltrasyon, reverse osmosis, textile wastewater, membrane filtration

\footnotetext{
*Sorumlu yazar: adem.yurtsever@hku.edu.tr

Geliş Tarihi: 28.07.2019, Kabul Tarihi: 06.12.2019
} 


\section{Giriş}

Su maliyetlerinde meydana gelen artış ve atıksu deşarj standartlarına uyma zorunluluğu birçok endüstri alanını atıksularını yeniden kullanmaya zorlamaktadır. Tekstil endüstrisi bu endüstrilerin başında gelmektedir. Tekstil endüstrisinde su; ağartma, boyama ve baskı gibi aşamalarda büyük miktarlarda kullanılır. Su tüketiminin, son ürünün kilogramı başına 200-400 L civarında olduğu tahmin edilmektedir [1]. Üretilen atık sular organik madde, sabitleyici maddeler, deterjanlar, boyalar ve tuzlardan türetilmiş ürünler içerir ve bu nedenle de deşarj edilmeden önce işleme tabi tutulmalıdır [2]. Tekstil atıksularının arıtımı için membran biyoreaktörler [3], kimyasal oksidasyon [4], elektrokimyasal yöntemler [5], biyolojik arıtma [6], adsorpsiyon [7,8] ve kimyasal koagülasyon [9] gibi birçok metot kullanılmaktadır. Su sıkıntısının bir sonucu olarak, geçmişte tekstil endüstrisi atıksuları kanalizasyona deşarj edilirken, günümüzde su kalitesi yeterli olduğunda prosesin çeşitli aşamalarında geri kullanılmaktadır. Bu nedenle dünyada ve Türkiye'de kullanılmış suların yeniden kullanımı üzerine teknolojiler son yıllarda giderek yaygınlaşmaktadır.

Tekstil endüstrisi çıkış suları üretim prosesinden kaynaklanan kalıntı tuzu da içermektedirler. Tuz, boyanın kumaşa bağlanması için gereklidir ve geri devir yapılan su tuz içerebilirken boya içermemelidir. Bu nedenle proses seçimi yapılırken seçici bir giderim büyük önem arz etmektedir. Bu durumda tuz ve boyar maddelerin moleküler özelliklerine ve büyüklüklerine göre bir süreç izlenmesi gerekir.

Nanofiltrasyon (NF) basınç ile yönetilen bir ayırım prosesidir ve bu süreçte boyar maddeler, tuzlar ve bazı diğer kirleticiler (ör: sülfat, sertlik vb.) giderilebilir [10]. Membran filtrasyon prosesleri içerisinde, nanofiltrasyon, ultrafiltrasyon ile ters ozmoz arasında bulunup MWCO değeri 100 ile 1000 Da arasındadır (gözenek çapı yaklaşık $1 \mathrm{~nm}$ ). Nanofiltrasyon sürecinde membranın iç yüzeyine ait mikro hidrodinamik özellikler sayesinde kirleticilerin yüzeyde tutunması sağlanır. Örnek olarak filtrasyon performansı membran yüzeyindeki yük dengesine bağlıdır [11]. Bazı endüstriyel sektörler düşük işetme basınc1, düşük maliyetleri, tekli ve çoklu iyonların ayrı ayrı tutulmaları gibi avantajlarından dolayı NF proseslerini tercih etmektedirler. Nanofiltrasyon yöntemleri, sahip olduğu avantajlar nedeni ile birçok endüstri tarafindan kabul görmüştür [11]. Lau ve İsmail (2009) yaptıkları derleme çalışmasında birçok ticari membranın yüksek akıda çalıştırılabildiklerini ya da yüksek performansta boya giderimi yapabildiklerini bildirmişlerdir. İdeal membranlar ise her iki özelliği de barındırmalıdır [12]. Membranın kirleticileri tutma yeteneği gözenek çapı membran yapısı gibi özelliklerin yanı sıra membran ile kirleticinin elektriksel yükleri arasındaki etkileşime de bağlıdır. Elektriksel olarak yüklü membran ilk olarak Erswell ve arkadaşları (1988) tarafindan kullanılmıştır. Membran performansı çeşitli işletim koşulları altında boya ve tuz ayrımı ve süzüntü akı değerleri baz alınarak değerlendirilmiştir. Çalışma sonunda nanofiltrasyon prosesinin yüksek miktarda su geri kazanımı ile boyar madde içeren atıksuların arıtımında uygulanabilir olduğu sonucuna varmışlardır [13]. Fakat 40 bara kadar basınç uygulanmasına rağmen sadece $30 \mathrm{~L} /\left(\mathrm{m}^{2} . \mathrm{h}\right)$ akı elde edilmiştir. Avlonitis ve arkadaşları (2008) [14] ise yaptıkları çalışmada pamuk boyama çıkış sularının nanofiltrasyon prosesi ile \%72'lik bir oranda tuz giderimi ile aritılabileceğini ortaya koymuştur.

Literatürde nanofiltrasyon ve ters ozmoz membranları ile tekstil atıksularının arıtılmasına yönelik bir dizi çalışma bulunmasına rağmen piyasada bulunan yaygın membranların birbirleri ile akı ve arıtabilirlik yönünden karşılaştırmalı çalışması henüz çalışılmamıştır. Bu çalışmada ise bir dizi nanofiltrasyon ve ters ozmoz membranı ile sonlu filtrasyon testleri yapılarak çeşitli basınçlar altında filtrasyon performansını belirlenmiş ve arıtım verimleri ortaya konmuştur. Bu süreç, membran yüzeyi ve kirletici moleküller arasındaki elektrostatik ilişkiden büyük oranda etkilenmektedir ve bu sürecin izlenebilmesi için anaerobik ve aerobik olarak arıtılmış gerçek tekstil endüstrisi atıksuyu farklı $\mathrm{pH}$ değerlerinde yalnızca NF270, NF90 ve NFTS40 membranı filtre edilmiş ve sonuçlar tartışılmıştır.

\section{Materyal ve Metot}

\subsection{Atıksu}

Çalışmada kullanılan atıksu tekstil endüstrilerinin yoğun olarak bulunduğu bir organize sanayi bölgesine ait atıksu arıtma tesisinin çıkışından alınmıştır. Bölgedeki işletmelerden kaynaklanan evsel ve endüstriyel nitelikli atıksuda, uzun havalandırmalı aktif çamur prosesi ile karbon, azot ve fosfor giderimi 
yapılmaktadır. Çalışmada kullanılan atıksu bu tesisin son çökeltim havuzu çıkışından alınmıştır. Atıksuya ait karakterizasyon Tablo 1'de görülmektedir. Atıksu arıtma tesisi çıkışından alınan su ise nanofiltrasyon ve ters ozmoz membranları ile filtre edilmeden önce, $0,45 \mu \mathrm{m}$ gözenek boyutuna sahip poliethersülfon (PES) mikrofiltrasyon membranı ile ön işleme tabi tutularak askıda katı maddelerin giderimi sağlanmıştır.

Tablo 1. Çalışmada kullanılan atıksuyun karakterizasyonu.

\begin{tabular}{|c|c|c|c|c|c|c|c|}
\hline \multirow[b]{2}{*}{ Membran } & \multirow[b]{2}{*}{ pH } & \multirow[b]{2}{*}{ İletkenlik $(\mu \mathrm{S} / \mathrm{cm})$} & \multirow[b]{2}{*}{ Renk Pt-Co $(465$ nm) } & \multicolumn{3}{|c|}{ Renklilik Sayısı (RES) } & \multirow{2}{*}{$\underset{(\mathbf{m g} / \mathbf{L})}{\mathbf{K O}}$} \\
\hline & & & & $436 \mathrm{~nm}$ & $525 \mathrm{~nm}$ & $620 \mathrm{~nm}$ & \\
\hline Atıksu & 8,2 & 4515 & 518 & 10,7 & 7,3 & 3,4 & 119 \\
\hline
\end{tabular}

\subsection{Sonlu Filtrasyon Mekanizması ve Kullanılan Membranlar}

Çalışmada kullanılan sonlu sistemi Şekil 1'de gösterilmektedir. Mekanizma, basıncı oluşturmak için bir azot tüpü, atıksuyun içine konacağı bir hazne $(250 \mathrm{ml})$ hazne sonunda membran bölmesi ve membran üzerinde çapraz akışı sağlayacak bir manyetik karıştırıcıdan oluşur. Filtre edilen su ise sürekli olarak hassas terazide ölçülür ve bu ölçümler bilgisayar ortamında kayıt edilir (Şekil 1).

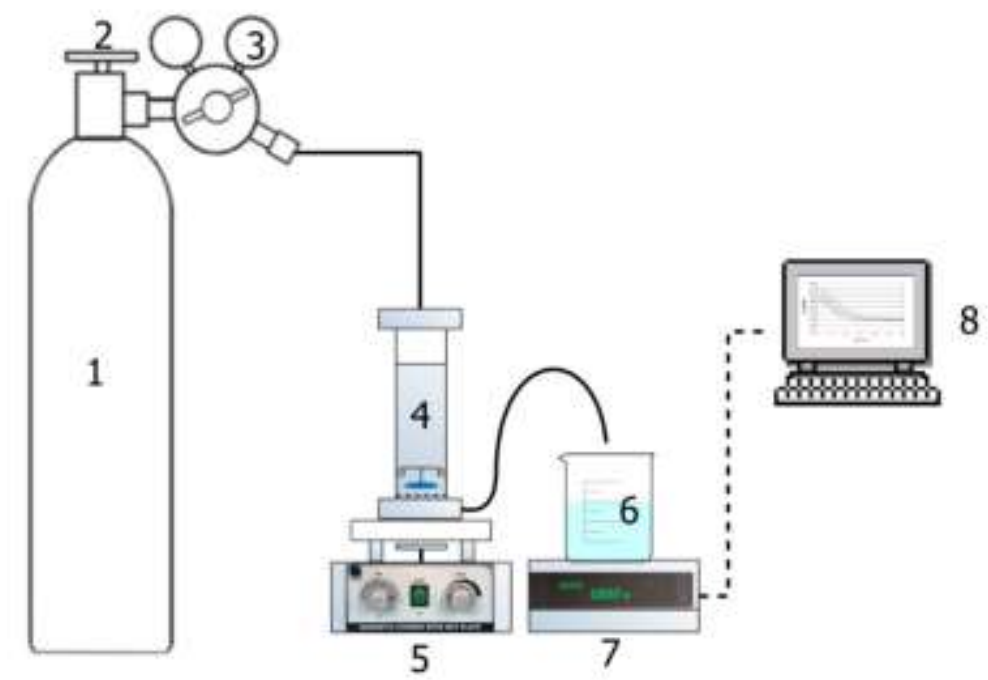

Şekil 1. Filtrasyon testlerinde kullanılan sonlu filtrasyon ünitesi (1, gerekli basıncı sağlamak için kullanılan azot gazı; 2, valf; 3, basınç göstergesi; 4, sonlu filtrasyon mekanizması; 5, manyetik karıştırıcı; 6, süzüntü toplama beheri; 7 , hassas terazi; 8 , bilgisayar.

Filtrasyon çalışması, konsantrasyon polarizasyonunun ölçülmesi amacıyla, filtrasyon testleri öncelikli olarak saf su, sonrasında atıksu ve tekrar saf su olacak şekilde döngüler halinde yapılmıştır. Atıksu filtrasyonundan önce ve sonra elde edilen saf su akıları arasındaki fark, konsantrasyon polarizasyonundan kaynaklanan akıdaki düşüşü vermektedir. Çalışmada membranın atıksu akıları, akı düşüşleri ve KOİ, renk ve iletkenlik giderim performansları incelenmiştir. Çalışmada 300 ml' lik hacme sahip su haznesi kullanılmış olup, 250 ml'lik aktif hacimde çalışmalar yürütülmüştür. Konsantrasyon polarizasyonunun azaltılması amacıyla membran yüzeyinde akış hızı oluşturulmuş olup, bunun için manyetik balık ve karıştırıcı kullanılmıştır (Şekil 1). Çapraz akış hızı membran tıkanıklığına etki eden önemli bir parametre olup, hız arttıkça suyun membran yüzeyinde biriken kek tabakasını sıyırıcı gücü de artar. Bu sayede konsantrasyon polarizasyonu ve jel tabakası oluşu azabilir [15]. Çalışmada öncelikle bütün membranlar için geçirgenlik testleri yapılmış olup, bunun için temiz membranda farklı basınç altında $(10,15,20$ ve 25 bar) saf su filtrasyonu yapılmıştır. Elde edilen akılar basınçlara bölünerek geçirgenlik hesaplanmıştır. Daha sonra seçilen 3 farklı NF membranı (NF90, NF270 ve NFTS40) için farklı $\mathrm{pH}$ değerlerinde $(3,7$ ve 10$)$ filtrasyon testleri yapılarak pH'nın membran filtrasyonu ve akıs1 üzerine etkileri belirlenmiştir. Yapılan her bir çalışmada arıtım performanslarının belirlenmesi için KOİ, iletkenlik ve renk ölçümleri yapılmıştır. 
Çalışmada 6 farklı NF membranı ile 3 ters ozmoz membranı kullanılmıştır. Bu membranlara ait özellikler Tablo 2'de sunulmuştur.

Tablo 2. Çalışmada kullanılan membranların özellikleri.

\begin{tabular}{|l|l|l|l|l|l|}
\hline $\begin{array}{l}\text { Özellikler/ } \\
\text { Membranlar }\end{array}$ & Polimer & $\begin{array}{l}\text { Moleküler } \\
\text { Ağırlı } \\
\text { Engelleme } \\
\text { Sinırı (MWCO) }\end{array}$ & $\begin{array}{l}\text { Tuz Giderme } \\
\text { Oranı }\end{array}$ & $\begin{array}{l}\text { pH Aralı̆ğ } \\
\left(\mathbf{2 5}{ }^{\circ} \mathbf{C}\right)\end{array}$ & $\begin{array}{l}\text { Tipik Akı/psi } \\
\text { GFD@ PSI }\end{array}$ \\
\hline NF90 & Polyamide & $\sim 100-200 \mathrm{Da}$ & - & $2-11$ & $46-60 / 130$ \\
\hline NF270 & Polyamide & $\sim 200-400 \mathrm{Da}$ & $99,2-\mathrm{MgSO}_{4}$ & $2-11$ & $72-98 / 130$ \\
\hline NFTS40 & $\begin{array}{l}\text { Polypiperazine } \\
\text { amide }\end{array}$ & $200 \mathrm{MWCO}$ & $99 \%-\mathrm{MgSO}_{4}$ & $2-11$ & $20 / 110$ \\
\hline NFXN45 & $\begin{array}{l}\text { Polypiperazine } \\
\text { amide }\end{array}$ & $500 \mathrm{MWCO}$ & $95.0 \%-\mathrm{MgSO}_{4}$ & $2-11$ & $35 / 110$ \\
\hline NFDK & TF (Thin Film) & $150-300 \mathrm{MWCO}$ & $98 \%-\mathrm{MgSO}_{4}$ & $2-10$ & $22 / 100$ \\
\hline NFDL & TF (Thin Film) & $150-300 \mathrm{MWCO}$ & $96 \%-\mathrm{MgSO}_{4}$ & $2-10$ & $31 / 100$ \\
\hline ROX201 & Polyamide-urea & - & $99,5 \%$ & $2-11$ & $30 / 225$ \\
\hline ROBW30FR & Polyamide & $\sim 100 \mathrm{D}$ & $99,5 \%$ & $2-11$ & $26 / 255$ \\
\hline ROACM5 & Polyamide & $0 \mathrm{MWCO}$ & $98,5 \%$ & $2-11$ & $30 / 110$ \\
\hline
\end{tabular}

\subsection{Verilerin Analizi}

\subsubsection{Akı, tuzluluk ve boya giderimi}

Membranın kullanılabilirliği membrandan geçen akı olarak ifade edilir. Saf su akısı JW (LMH) olarak tanımlanmıştır:

$$
\mathrm{JW}=\mathrm{Qw} /(\text { A.t })
$$

Burada; Qw, Saf su için elde edilen süzüntünü hacmi (Litre), A, Membran alanı $\left(\mathrm{m}^{2}\right), \mathrm{t}$ ise toplama zamanı (saat)'dır.

Tuzluluk ve boya içeren atıksuyun filtrasyonu sırasında elde edilen Akı (Jsd) ise şu şekilde ifade edilir:

$$
\mathrm{Jsd}=\mathrm{Qs} /(\mathrm{Axt})
$$

Burada; Qs, atıksu testleri sırasında süzüntünün hacmini ifade eder.

Gözlemlenen tuz giderimi (R0) ise aşağıdaki denklem kullanılarak hesaplanmıştır.

$$
\mathrm{R} 0(\%)=(\mathrm{Cb}-\mathrm{Cp}) / \mathrm{Cb} * 100
$$

Burada, $\mathrm{Cb}$ ve $\mathrm{Cp}$ sırasıyla atıksudaki ve süzüntüdeki tuz konsantrasyonudur.

Gerçek giderim ise R ile sembolize edilir ve aşağıdaki denklem kullanılarak hesaplanır:

$$
\mathrm{R}=(\mathrm{Cm}-\mathrm{Cp}) / \mathrm{Cm} * 100
$$

Burada; $\mathrm{Cm}$, membran yüzeyindeki kirletici konsantrasyonu, $\mathrm{Cp}$ ise kirleticinin süzüntüdeki konsantrasyonudur.

Boya giderimi ise şu şekilde tanımlanır:

$\mathrm{R} 0$ boya $(\%)=(\mathrm{Ab}-\mathrm{Ap}) / \mathrm{Ab} * 100$

Gerçek giderim ise:

$$
\mathrm{R} \text { boya }(\%)=(\mathrm{Ab}-\mathrm{Ap}) / \mathrm{Am} * 100
$$


Burada; Ab ve Ap, atıksu ve süzüntüdeki boya konsantrasyonu olup, Am = Membran yüzeyindeki boya konsantrasyonudur.

Ayrıca her bir membran için hacim azaltma faktörleri (volume reduction factor: VRF) aşağıdaki şekilde hesaplanmıştır.

$\mathrm{VRF}=\mathrm{Vi} /(\mathrm{Vi}-\mathrm{Vs})$

Burada, Vi ve Vs sirasıyla ilk hacim ve membrandan çekilen süzüntü hacmini göstermektedir.

\subsection{Analitik Metotlar}

Filtrasyon sonrası elde edilen süzüntüden KOİ, $\mathrm{pH}$, iletkenlik ve renk tayini yapılmıştır. KOİ testi, düşük aralık KOİ kiti ile yapılmıştır (Hach $5-60 \mathrm{mg} / \mathrm{L}$ ). pH ve iletkenlik ise Hach marka $\mathrm{pH}$ metre ile ölçülmüsstür (Hach - HQ 40d pH meter). Renk ise Hach Marka spektrofotometre ile 460 nm'de Pt-Co olarak analiz edilmiştir [16].

\section{Bulgular ve Tartışma}

\subsection{Membranların Birbirleri ile Kıyaslanmaları}

Atıksu filtrasyonları sırasında elde edilen atıksu geçirgenlik değerleri, her bir membran için saf su geçirgenliği ile kıyaslanmıştır ve zamana göre değişen geçirgenlik değerleri Şekil 2'de gösterilmektedir. RO membranları içinde ROX201 akıdaki azalma açısından en yüksek performansı göstermiştir. Akıdaki azalma test süresinin başında saf su akısına göre \%8,24 ile başlayıp 25 Bar basınç altında 1 saatlik döngü sonunda \%29,41 değerine ulaşmıştır (Hacim Azaltma Faktörü: Volume Reduction Factor $(V R F)=1,51$ ). En yüksek akı RO-ACM5 membranı ile elde edilmiştir. Ortalama geçirgenlik değerleri ROBW30FR, ROACM5 ve ROX201 için 1,91, 2,95 ve 2,10 L/( $\mathrm{m}^{2}$.h.Bar)'dır.

ROBW30FR membranı 100 Da'lık MWCO ile poliamid bir membrandır. Akının arttırılabilmesi için sülfürik asit ve hidroflorik asit ile bir hidrofilikleştirme prosedürü önerilmiş ve artan membran performansı elde edilmiştir [17]. Mevcut çalışmada BW30FR ile 25 barlık basınç altında 1 saat sonunda atıksu akısındaki azalma saf suya nazaran \% 0 ile başlayıp 27,13'e yükselmiştir.

NF membranları için en yüksek geçirgenlik değeri NF270 membranı ile ortalama 5,95 L/(m².h.Bar) olarak bulunmuştur. Bu membran için akıdaki azalma \%38,75 ile başlayıp \%83,74'ye ulaşmışıtır (VRF 2,24 olmuştur). Akıda en düşük azalma NFDK membranında gözlemlenmiş olup 10, 15, 20 ve 25 Bar için 1 saatlik filtrasyon sonunda azalma sirasıly $\% 0,8,70,13,44$ ve 24,30'dur. NFDK membranı \%98'lik $\mathrm{MgSO}_{4}$ tutma özelliği ile 150-300 MWCO değerine sahiptir. Bu membran için üretici tarafından verilen geçirgenlik ise gıda endüstrisi atıksuları için tipik olarak $5.42 \mathrm{~L} . /\left(\mathrm{m}^{2}\right.$.h.bar)'dır. Tekstil endüstrisi çıkış suları için, aynı değer çalışmamızda $2,26 \mathrm{~L} /\left(\mathrm{m}^{2}\right.$.h.Bar) olarak tespit edilmiştir. $\mathrm{Bu}$ düşük geçirgenlik genel olarak membran yüzey özellikleri ve atıksu içerisindeki boyar maddelerin yükleri ile ilişkilidir. NFDK membranı yüksüz organik moleküller için yaklaşık 150-300 daltonluk MWCO değeri ile karakterize edilen ince bir film membranıdır. Öte yandan en yüksek akı düşüşü NFXN45 membanında gözlenmiştir ( 25 Bar ile atıksu ile yapılan testte saf suya göre başlangıçta $\% 0$ olan azalma sonrasında \%62,10'a yükselmiştir). Her bir NF için atıksu geçirgenlikleri ve bu değerlerdeki düşüşler Şekil 3’te gösterilmiştir.

Yapılan bir çalışmada süt endüstrisi atıksularından farklı NF ve TO membranlarıyla su geri kazanılması çalışılmış olup, çalışmada NF membranları için 15 bar altında 3,5-5 LMH'lık elde edilmiştir (VRF yaklaşık 3). Aynı VRF değeri için 25 bar basınç altında TO membranları için de 3,5-4 LMH arasında akı elde edilmiştir [18]. Bu sonuçlarla çalışmada NF ve TO membranları için en yüksek geçirgenlik değeri sırasıyla $0,33 \mathrm{LMH} /$ bar ve $0,16 \mathrm{LMH} /$ bar olarak elde edilmiş olup, bu çalışmada elde edilen geçirgenlik değerlerinden oldukça düşük seviyelerdedir. Bunun temel nedeni ise yüksek organik madde konsantrasyonundan (KOİ: 36 g/L) kaynaklandığg vurgulanmıştır. Özellikle kazeinler, peynir altı suyundan gelen proteinler ve laktoz kaynaklı olarak membran üzerinde jel tabakasının oluştuğu ve bu dinamik tabakanın, akı koşullarının sınırlandırılmasına yol açan aktif katman olduğu belirtilmiştir [18]. 

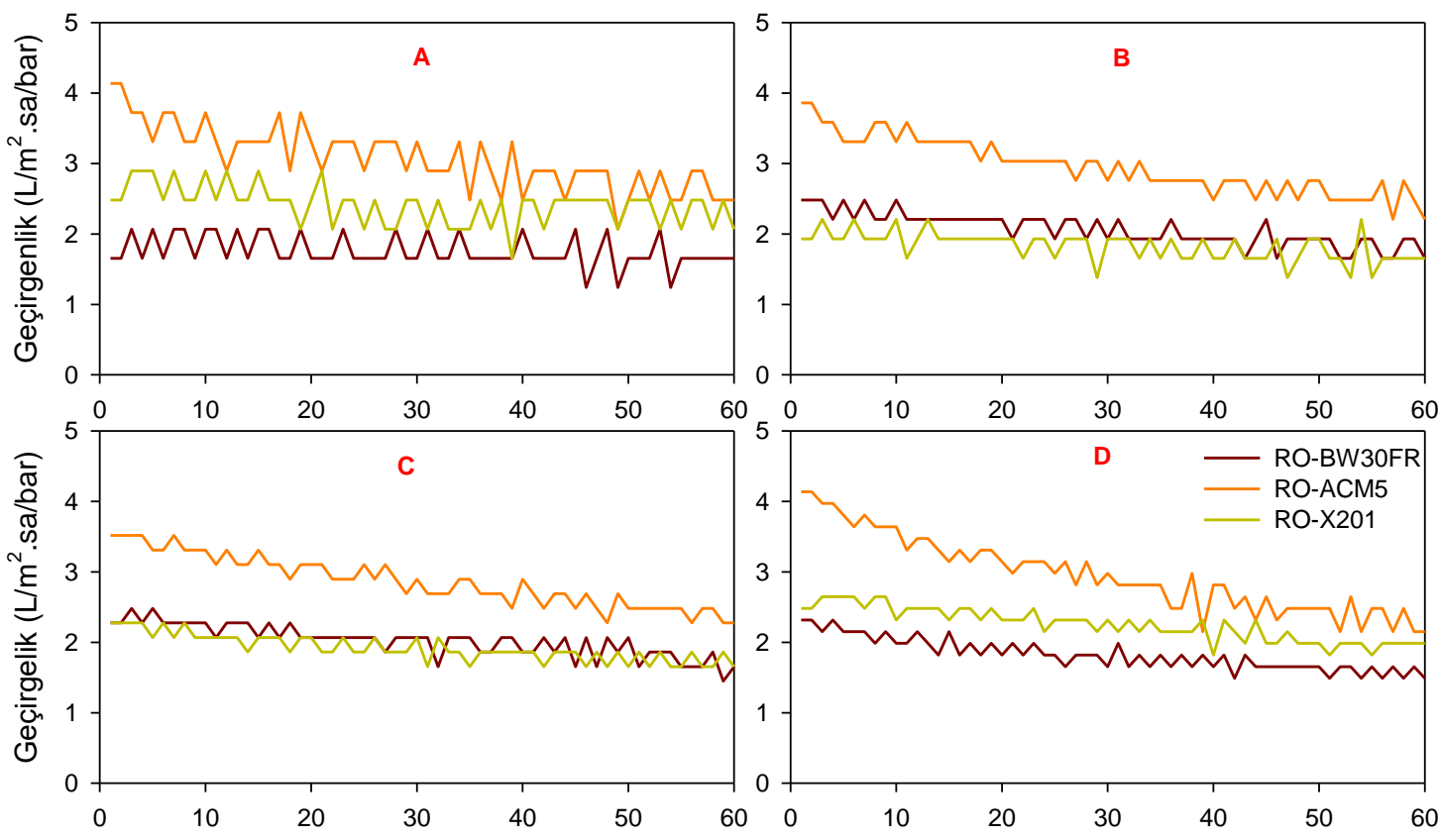

Filtrasyon Zamanı (dk)

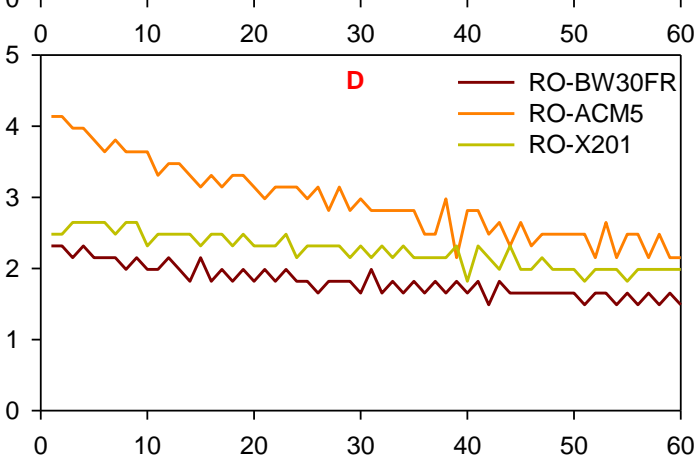

Filtrasyon Zamanı (dk)

Şekil 2. Farklı basınçlar altında RO membranları ile atıksu geçirgenliklerı (a:10 Bar; b: 15 Bar; c:20 Bar; d:25 Bar) Saf su geçirgenlikleri: ROBW30FR: 2,30 L/(m².h.Bar); ROACM5: 5,27 L/(m².h.Bar); ROX201: 2,96 $\mathrm{L} /\left(\mathrm{m}^{2}\right.$.h.Bar $)$
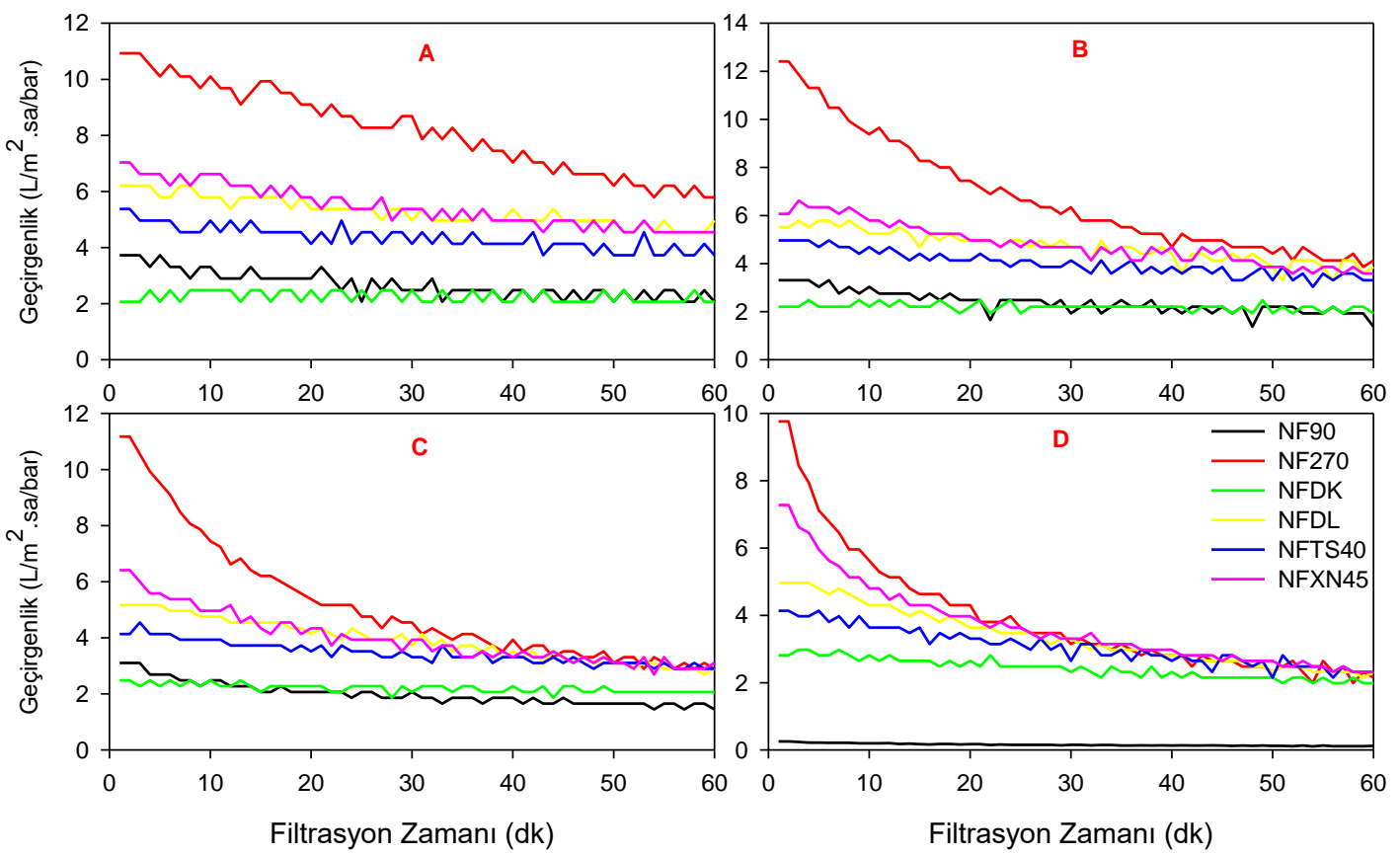

Şekil 3. Çeşitli basınç değerleri altında test edilen NF membranları. (a: 10 Bar; b:15 Bar, c:20 Bar ve d:25 Bar). Saf su geçirgenlikleri: NF90, 7.41 L/(m².h.Bar); NF270, 13.78 L/(m².h.Bar); NFDK, 2.77 L/(m².h.Bar); NFDL,

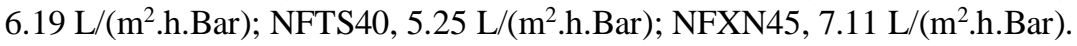


Suksaroj ve arkadaşları (2005) tarafından yapılan bir çalışmada, biyolojik olarak arıtılmış olan tekstil endüstrisi atıksuyu geri kazanımı çalışılmış olup, NF (Osmonics Desal 5 Dk) ve TO (Filmtec Cycron) membranları koagülasyon/flokülasyon ile ön arıtım yapılarak ve ön arıtım yapılmayarak kıyaslanmıştır [19]. Yapılan çalışmada kullanılan atıksu 1400-1800 $\mu \mathrm{S} / \mathrm{cm}$ iletkenlik değerine sahip olup, ön arıtma uygulanmış olan atıksuda NF membranında 12,5 bar basınç altında 17,9 LMH'lık akı elde edilmiştir (Geçirgenlik: 1,43 L/( $\mathrm{m}^{2}$.h.Bar)). Bu değer bu çalışmada kullanılan NF membranlarından elde edilen geçirgenlik değerinden yüksek olup, bu durumunda iki muhtemel nedeni olduğu söylenebilir. Bunlardan birincisi, sisteme beslenen atıksudaki iletkenlik değerinin bu çalışmada kullanılan iletkenlik değerinden oldukça düşük seviyelerde olması ve ikincisi ise atıksuya ön arıtım uygulanmasıdır. Benzer şekilde, yapılan çalışmada TO membranında ise 15 bar basınç altında 9,8 LMH'lık akı elde edilmiş olup (Geçirgenlik: 0,65 L/( $\mathrm{m}^{2}$.h.Bar)) [19], çalışmamızda elde edilen değerlerden yüksek seviyelerdedir. TO membranlarında da elde edilen bu değerlerin sebebi NF membranlarındaki ile aynıdır. Ayrıca yapılan çalışmada da ön arıtım uygulanan atıksuda elde edilen akının ön arıtım uygulanmayan atıksudan daha yüksek elde edildiği ve ön arıtımın filtrasyon akısını arttırdığı vurgulanmıştır [19].

\subsection{Atıksu akısına pH'nın etkisi}

Şekil 4'te üç nanofiltrasyon membranına ait pH 3, 7 ve 10'da NF90, NF270 ve NFTS40 membranlarına ait atıksu akıları yer almaktadır. En yüksek akı düşüşü her üç pH değeri için NF90 membranında elde edilmiştir. Çalışma başındaki saf suya nazaran hesaplanan akı düşüşleri \%75,19, 66,07 ve 67,53 iken pH 3, 7 ve 10 değerleri için çalışma sonunda sırasıyla \% 88,2, 81,73 ve 83,76 'ya yükselmişlerdir. Atıksu denemelerinden sonra da membranlar bir sünger ile fiziksel olarak temizlenmiş ve tekrardan saf su akılarına bakılarak başlangıç saf su akıları ile kıyaslanmıştır. Farklı pH değerleri için atıksu akı düşüş değerleri Şekil 4'te gösterilmektedir.

NF270 ve NFTS40 membranları NF90 membranından farklı olarak daha iyi akı değerleri göstermiş̧tir. pH 3 ve 7 değerinde NF270 membranı akısında benzer miktarda düşüş gözlenmiştir ( $\mathrm{pH} 3$ ve 7 için surasıyla \%35,07'ten 79,81'e ve \% 31,18'den 75,72'e). Fakat pH 10'da akı düşüşü \%45,46 ile başlayıp \%83,23'e yükselmiştir. pH'nın 3'ten 10'a yükselmesi akı geri kazanımını da arttırmıştır. Şekil 5 'ten de görülebileceği gibi, $\mathrm{pH} 10$ değerinde saf su akısı neredeyse tamamen testin başlangıcındaki değerlere eşittir.

Asidik pH'larda boya molekülleri daha az ayrışmaya sebep olup boya molekülü ile membran yüzeyi arasındaki ilişki yoğunluk kazanabilmektedir. $\mathrm{Bu}$ da boya moleküllerinin membran yüzeyine adosorpsiyonunu arttırıp akıyı düşürmektedir. $\mathrm{pH}$ değerinin 7'ye yükselmesi ile membran yüzeyindeki negatif yük yükselmeye başlar ve negatif yüklenmiş membran ile boya molekülleri arasındaki itme daha az gözenek tıkanmasına sebep olur. Bu da artan pH ile birlikte NF270 membranının akısının artmasına sebep olur. pH'nın 10'a arttırılması ise akıda daha fazla artışa sebep olmazken akı geri kazanımının artmasina sebep olmuştur.

NFTS40 membranı akısında daha az düşme gözlenmiş ve yüksek akı geri kazanımı elde edilmiş̧ir. En yüksek akı nötral pH'da NFTS40 membranı için elde edilmiştir. Giriş suyu pH'sından bağımsız olarak, membran fiziksel temizleme ile saf su akısına geri kavuşmuştur. Bu duruma pH'nın önemli bir derecede katkıs1 yoktur. Poliamid membranlardan farklı olarak, NFTS40 bir polipiperazin amid membranıdır. Atıksu testlerinde saf su akısına göre akı düşüşü \%19,67, \%5,57 ve \%13,75 ile başlayıp pH 3, 7 ve 10 için \% 53, 42,90 ve 55,12'ye yükselmiştir. Test sonundaki saf su akısındaki düşüş ise $\mathrm{pH} 3$, $\mathrm{pH} 7$ ve $\mathrm{pH} 10$ için \% 10,80, 8,30 ve 9,44'dur. Su ve atıksu geçirgenlikleri ayrıca birim bar başına elde edilen LMH değerleri olarak da değerlendirilmiştir. Aşağıdaki Şekil 6,7 ve 8'de başlangıçtaki saf su, atıksu ve çalışma sonunda elde edilen saf su geçirgenlik değerleri her bir membran için verilmiştir.

Çalışmanın bu kısmına göre, NF270 membranı için ortalama saf su geçirgenlikleri pH 3, 7 ve 10 için $10,11 \pm 0,08,11,02 \pm 0,15$ ve $11,68 \pm 0,16 \mathrm{~L} /\left(\mathrm{m}^{2}\right.$.h. Bar)'dır. Sonraki süreçte yapılan atıksu testinde ise ortalama geçirgenlik değerleri aynı $\mathrm{pH}$ değerleri için $3,39 \pm 1,42,4,26 \pm 1,53$ ve $2,98 \pm 1,34$ $\mathrm{L} /\left(\mathrm{m}^{2}\right.$.h.Bar)'dır. Son olarak çalışma sonunda yapılan saf su geçirgenlikleri ise aynı sıraya göre $3,40 \pm 1,13,9,68 \pm 0,35$ ve $11,85 \pm 0,64 \mathrm{~L} /\left(\mathrm{m}^{2}\right.$.h.Bar)'dır. 


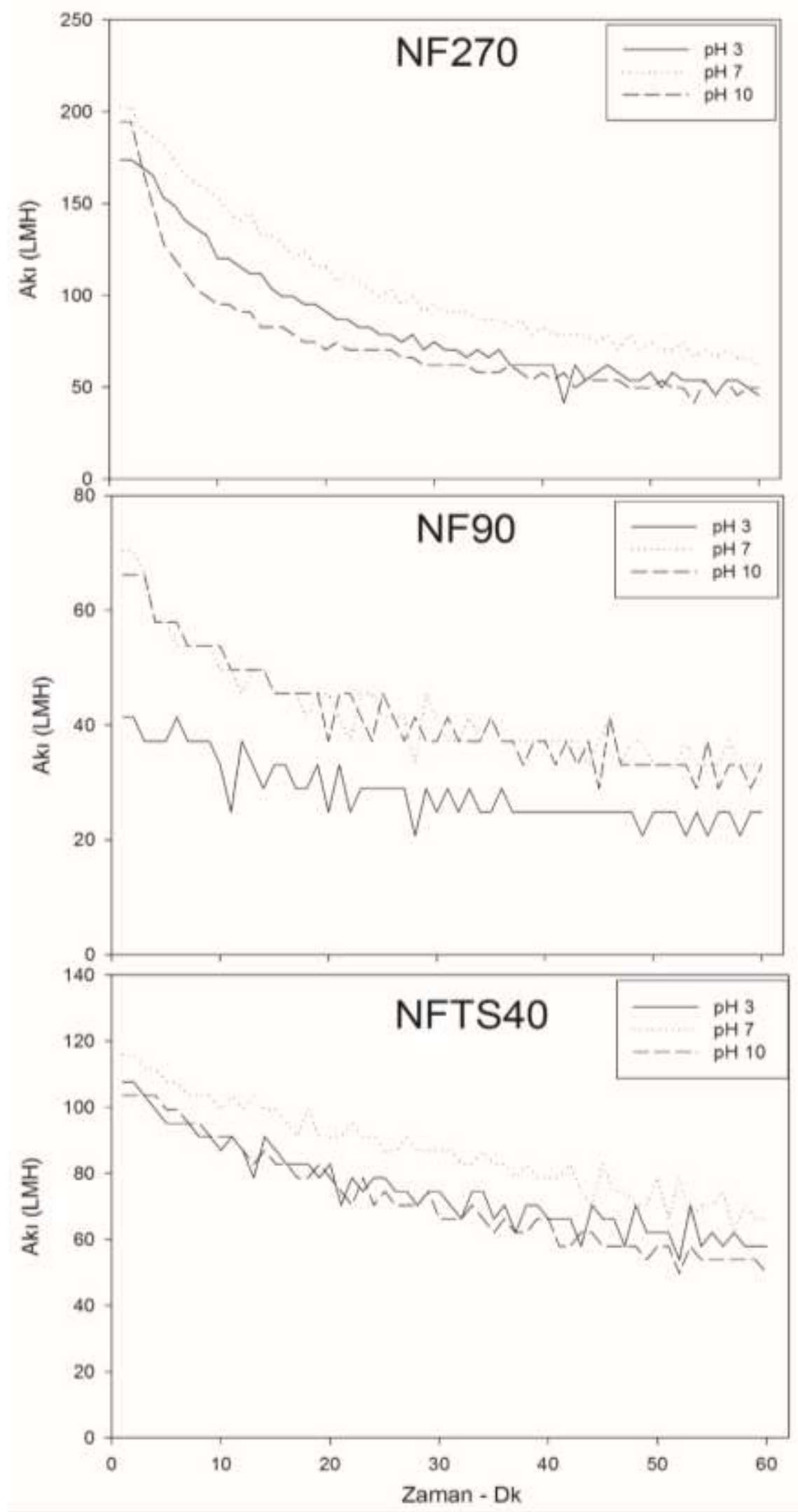

Şekil 4. Farklı pH değerleri için 25 Bar basınç altında NF270, NF90 ve NFTS40 için atıksu akıları. 

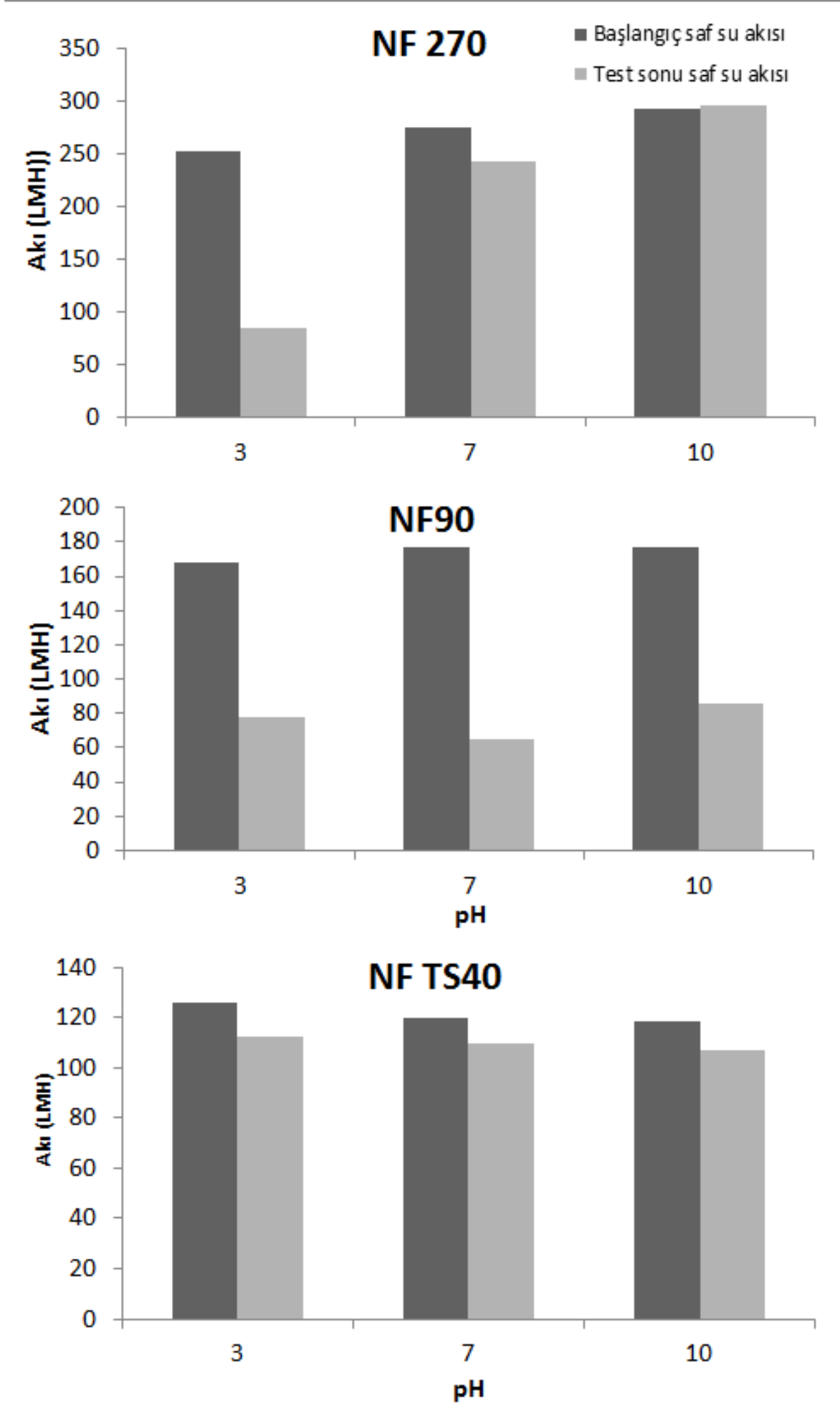

Şekil 5. Farklı pH'larda NF270, NF90 ve NFTS40 membranlarının saf su geçirgenlikleri. 


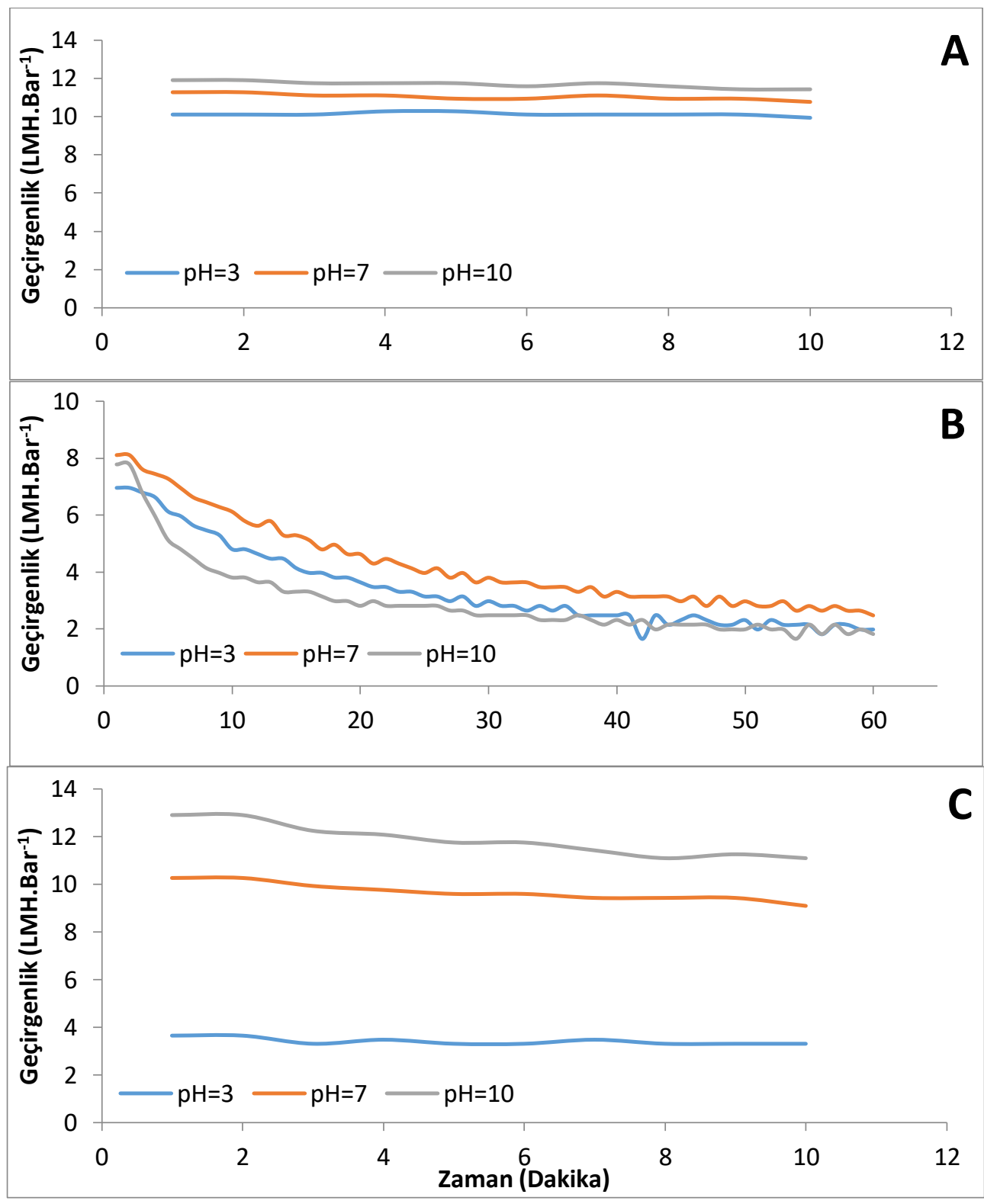

Şekil 6. NF270 membranı için 25 Bar basınç altında farklı pH'larda geçirgenlik değerleri (a: Başlangıçtaki saf su geçirgenliği, b: atıksu geçirgenliği ve c: çalışma sonundaki saf su geçirgenliği). 


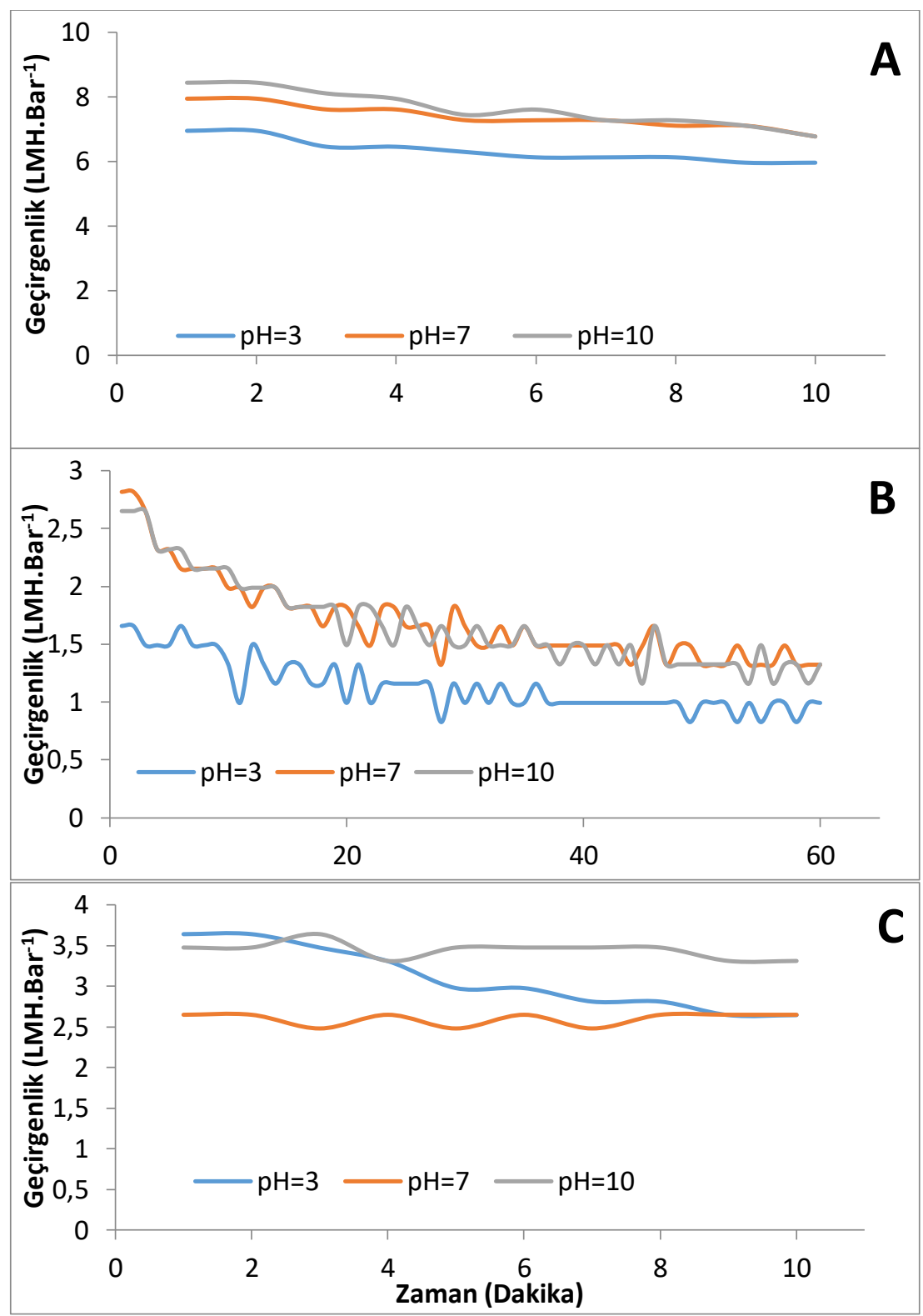

Şekil 7. NF90 membranı için farklı pH'larda geçirgenlik değerleri (a: Başlangıçtaki saf su geçirgenliği b: atıksu geçirgenliği ve c: çalışma sonundaki su geçirgenliği).

NF90 membranı için saf su geçirgenlik değerleri çalışma öncesinde $\mathrm{pH} 3,7$ ve 10 için $6,33 \pm 0,34,7,40 \pm 0,35$ ve $7,64 \pm 0,3 \mathrm{~L} /\left(\mathrm{m}^{2}\right.$.h.Bar) olarak belirlenmiştir. Çalışma sonunda ise saf su geçirgenlikleri $3,09 \pm 0,37,2,60 \pm 0,07$ ve $3,44 \pm 0,1 \mathrm{~L} /\left(\mathrm{m}^{2}\right.$.h.Bar)'a düşmüşsür (Şekil 7). Ortalama atıksu geçirgenliği ise $1,33 \pm 0,22,1,7 \pm 0,36$ ve $1,66 \pm 0,38 \mathrm{~L} /\left(\mathrm{m}^{2} . h\right.$. Bar)'tır. Atıksu geçirgenliği $\mathrm{pH} 7$ değeri için 2,58'den $1,35 \mathrm{~L} /\left(\mathrm{m}^{2}\right.$.h.Bar)'a düşmüştür. Oldukça benzer geçirgenlik düşüşleri $\mathrm{pH} 10$ için de gözlemlenmiştir. Bu pH 'da geçirgenlik 2,51'den 1,3 L/( $\mathrm{m}^{2}$.h.Bar)'a düşmüştür. En düşük geçirgenlik düşüşü $\mathrm{pH}$ 3'te test edilen atıksuda gözlemlenmiştir. Bu testte geçirgenlik 1,57 den 0,93 L/( $\mathrm{m}^{2}$.h.Bar)'a düşmüştür (Şekil 7b).

NFTS40 membranına ait geçirgenlik değerleri de Şekil 8'de görülmektedir. pH 3, 7 ve 10 için geçirgenlik düşüşleri sırasıyla 5,04 $\pm 0,13$ 'den $4,50 \pm 0,16$ 'a; 4,78 $\pm 0,28$ den $4,38 \pm 0,18$ 'a ve $4,73 \pm 0,08$

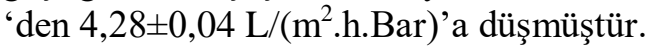




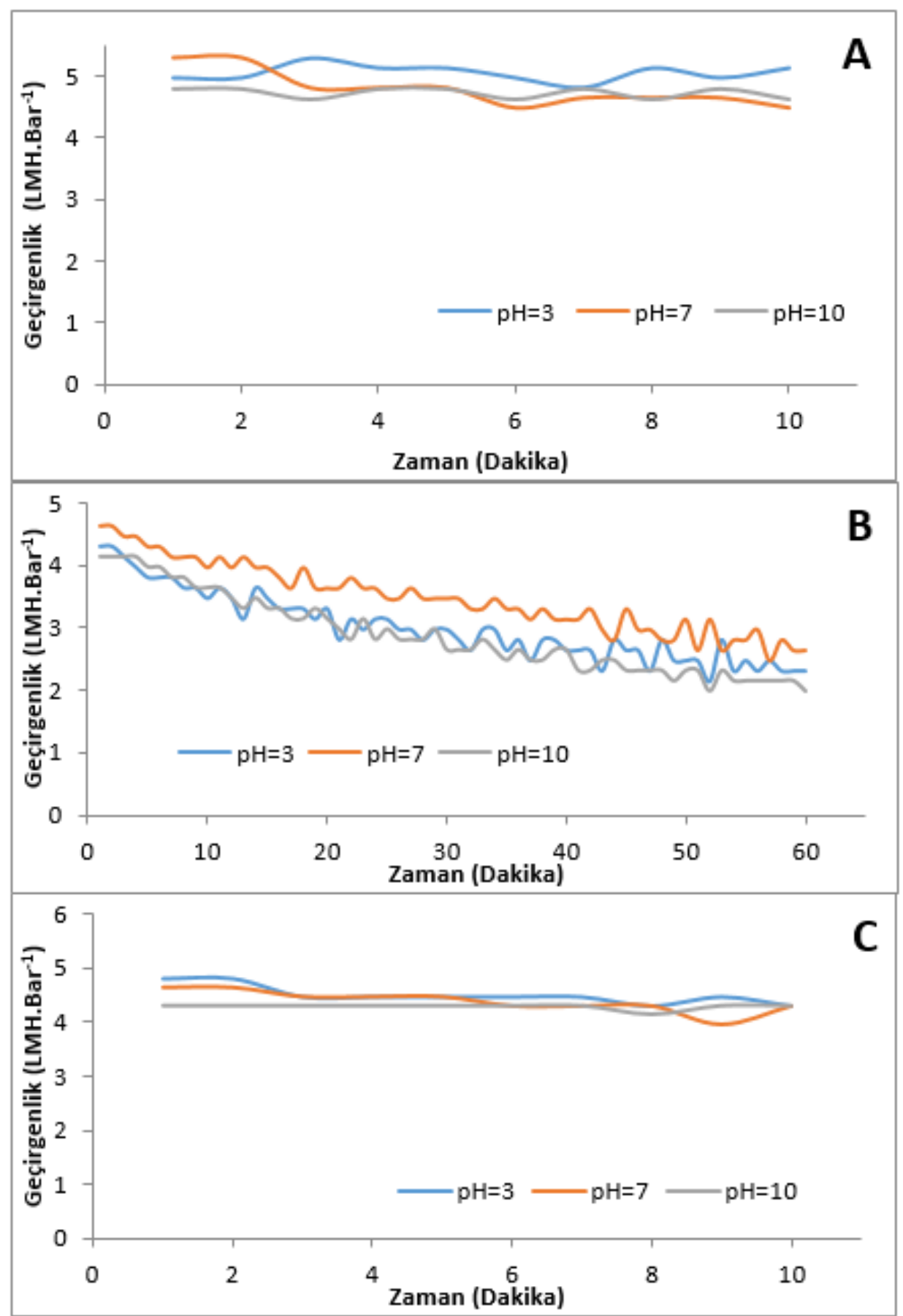

Şekil 8. NFTS40 membranına ait farklı pH'lardaki geçirgenlik değerleri (a: Başlangıçtaki saf su geçirgenliği, b: atıksu geçirgenlik değeri ve c: çalışma sonundaki saf su geçirgenliği).

\subsection{Ters Ozmoz ve Nanofiltrasyon Membranları için Arıtma Performansları}

Her bir filtrasyon alternatifine göre elde edilen VRF değerleri Tablo 3'de verilmiştir. Elde edilen süzüntülerden her bir döngü sonunda örnekler alınarak $\mathrm{pH}$, iletkenlik, renk ve KOİ analizleri yapılmıştır. Tablo 3 ters ozmoz membranları için arıtım performanslarını göstermektedir. Beklendiği üzere ters ozmoz membranları yüksek seviyede renk ve iletkenlik giderimi sağlamıştır. ROBW30FR membranı için KOİ değeri 1 saatlik süren filtrasyon sonucunda ölçülmüş ve $120 \mathrm{mg} / \mathrm{L}$ 'den $12 \pm 0,2 \mathrm{mg} / \mathrm{L}$ 'ye düşmüştür. 1 saatlik çalışma sonunda 25 Bar basınç altında VRF 1,36 değerine ulaşmıştır. Süzüntü iletkenliği ise $173 \pm 0,28 \mu \mathrm{S} / \mathrm{cm}$ olup bu değer $\% 96,16^{\prime}$ 'lık bir giderime tekabül etmektedir. Süzüntü renk giderimi ise $\% 100$ olup çıkıș boya konsantrasyonu tespit edilebilir seviyenin altında bulunmuştur. ROACM5 membranı da yüksek KOİ, iletkenlik ve renk giderim performansı göstermiştir. 25 Bar basınç 
altında sırasıyla \%96,11, 98,84 ve 91,09 oranlarında iletkenlik, renk ve KOİ giderimi gerçekleşmiştir. ROX201 membranı da benzer ayırım özellikleri göstermiştir. İletkenlik 117,4 $\mu \mathrm{S} / \mathrm{cm}$ 'ye düşerek \%97,4'lük bir giderim göstermiştir. Renk ve KOİ ise sirasıyla $5 \mathrm{Pt}$-Co ile $11,46 \mathrm{mg} / \mathrm{L}$ olarak bulunmuştur. TO membranlarına ait test edilen tüm parametreler Tablo 3 'de verilmiştir.

Tablo 3. Ters ozmoz membranlarının arıtım performansları.

\begin{tabular}{|c|c|c|c|c|c|c|c|c|c|}
\hline \multirow{2}{*}{ Membran } & \multirow{2}{*}{$\begin{array}{l}\text { Basınç } \\
\text { (Bar) }\end{array}$} & \multirow{2}{*}{ VRF } & \multirow{2}{*}{ pH } & \multirow{2}{*}{$\begin{array}{c}\text { İletkenlik } \\
(\mu \mathrm{S} / \mathrm{cm})\end{array}$} & \multirow{2}{*}{$\begin{array}{l}\text { Renk Pt-Co } \\
(465 \text { nm) }\end{array}$} & \multicolumn{3}{|c|}{ RES } & \multirow{2}{*}{$\begin{array}{c}\text { KOİ } \\
(\mathrm{mg} / \mathrm{L})\end{array}$} \\
\hline & & & & & & $436 \mathrm{~nm}$ & $525 \mathrm{~nm}$ & $620 \mathrm{~nm}$ & \\
\hline Atıksu & - & & 8,2 & 4515 & 518 & 10,722 & 7,370 & 3,404 & 119 \\
\hline \multirow{4}{*}{$\begin{array}{l}\text { RO } \\
\text { BW30FR }\end{array}$} & 10 & 1,11 & 6,9 & 234 & 4 & 0,466 & 0,232 & 0,234 & 7,4 \\
\hline & 15 & 1,22 & 6,8 & 162 & 12 & 0,933 & 0,464 & 0,467 & 16 \\
\hline & 20 & 1,30 & 6,7 & 119 & 0 & 0,000 & 0,000 & 0,000 & 11 \\
\hline & 25 & 1,35 & 6,9 & 173 & 0 & 0,000 & 0,000 & 0,000 & 11 \\
\hline \multirow{4}{*}{ RO X201 } & 10 & 1,16 & 7,2 & 271 & 15 & 2,332 & 1,393 & 1,168 & 4,4 \\
\hline & 15 & 1,19 & 6,7 & 107 & 13 & 2,332 & 1,393 & 0,934 & 6,2 \\
\hline & 20 & 1,28 & 6,5 & 89 & 11 & 1,865 & 1,161 & 0,701 & 10 \\
\hline & 25 & 1,50 & 7,5 & 117 & 5 & 0,233 & 0,232 & 0,234 & 11,5 \\
\hline \multirow{4}{*}{$\begin{array}{l}\text { RO } \\
\text { ACM5 }\end{array}$} & 10 & 1,21 & 7,8 & 126 & 29 & 4,663 & 3,483 & 2,569 & 7 \\
\hline & 15 & 1,34 & 6,5 & 85 & 25 & 3,964 & 3,251 & 2,102 & 8 \\
\hline & 20 & 1,50 & 6,5 & 110 & 19 & 3,264 & 2,090 & 1,401 & 9 \\
\hline & 25 & 1,74 & 6,7 & 176 & 6 & 1,632 & 0,929 & 0,467 & 11 \\
\hline
\end{tabular}

Nanofiltrasyon membranları için arıtım verimleri membrana bağlı olarak farklılık göstermiştir. En düşük çıkış iletkenlik değeri NF90 membranı ile 25 Bar basınç altında $218,65 \pm 0,63 \mu \mathrm{S} / \mathrm{cm}$ olarak ölçülmüş ve bu değeri NFDK membranı $1559 \mu \mathrm{S} / \mathrm{cm}^{\prime}$ lik çıkış iletkenlik değeri ile takip etmiş̧ir. Diğer yandan XFNF45 membranı ise en düşük iletkenlik giderim performansını göstermiştir (25 Bar basınç altında $3420 \mu \mathrm{S} / \mathrm{cm}$ ). Tablo 2'den de görüldügüü üzere diğer NF membranlarına kıyasla daha düşük gözenek boyutundan ( 100-200 Da) dolayı NF90 membranı daha iyi iletkenlik giderimi gerçekleştirmiştir. Bunun Donnan etkisi nedeniyle olduğu tahmin edilmektedir. Renk giderimi neredeyse tüm membranlar için stabildir. Çıkış renk konsantrasyonları en düşük NF90 ve NF270 membranı ile 4 Pt-Co olarak ölçülürken en yükdek değer XFNF45 membranı ile 114 Pt-Co'dır. NF90 ve NF270 membranları 4 Pt-Co çıkış renk konsantrasyonu ile maksimum renk giderim verimleri (Her iki membran için 25 Bar basınç altında $>\% 99$ 'dan fazla) göstermiştir. Süzüntü renk konsantrasyonu XFNF45 membranı için 114 Pt-Co'dur. Bu değer test edilen membranlar arasındaki en düşük verim olsa da çıkış suyu halen atıksu deşarj standartlarını karşılamaktadır. Türkiye için deşarj standardı $280 \mathrm{Pt}-$ Co'dur. COD konsantrasyonları $<4 \mathrm{mg} / \mathrm{L}$ ile $39,21 \pm 6,85 \mathrm{mg} / \mathrm{L}$ arasında değişmektedir. Test edilen herbir membran için süzüntü KOİ konsantrasyonları Tablo 3 'te gösterilmiştir. Görüleceği üzere NF90, NF270 ve NFDL oldukça yüksek KOİ giderim verimi göstermiştir. Test edilen tüm NF membranlara ait KOİ, renk ve iletkenlik giderim değerleri Tablo 4'te gösterilmiştir. 
Tablo 4. Test edilen NF membranlarına ait iletkenlik, renk ve KOİ giderim verimleri.

\begin{tabular}{|c|c|c|c|c|c|c|c|c|c|}
\hline Membran & $\begin{array}{l}\text { Basınç } \\
\text { (Bar) }\end{array}$ & VRF & pH & $\begin{array}{l}\text { İletk. } \\
(\mu \mathrm{S} / \mathrm{cm})\end{array}$ & $\begin{array}{c}\text { Renk Pt-Co } \\
\text { (465 nm) }\end{array}$ & $436 \mathrm{~nm}$ & $525 \mathrm{~nm}$ & $620 \mathrm{~nm}$ & $\begin{array}{l}\text { KOİ } \\
(\mathrm{mg} / \mathrm{L})\end{array}$ \\
\hline Atıksu & - & - & 8,2 & 4515 & 518 & 10,722 & 7,370 & 3,404 & 119 \\
\hline \multirow{4}{*}{ NF90 } & 10 & 1,18 & 6,83 & 263 & 4 & 0,233 & 0,000 & 0,000 & $<4 \mathrm{mg} / \mathrm{L}$ \\
\hline & 15 & 1,27 & 6,86 & 257 & 0 & 0,233 & 0,000 & 0,000 & 8,8 \\
\hline & 20 & 1,29 & 6,91 & 300 & 8 & 0,466 & 0,232 & 0,234 & $<4 \mathrm{mg} / \mathrm{L}$ \\
\hline & 25 & 1,33 & 6,82 & 219 & 4 & 0,233 & 0,000 & 0,000 & $<4 \mathrm{mg} / \mathrm{L}$ \\
\hline \multirow{4}{*}{ NF270 } & 10 & 1,85 & 8,01 & 3125 & 8 & 1,399 & 0,697 & 0,234 & 12,3 \\
\hline & 15 & 2,36 & 8,10 & 2970 & 12 & 0,699 & 0,464 & 0,234 & 14,4 \\
\hline & 20 & 2,40 & 8,03 & 2770 & 0 & 0,000 & 0,000 & 0,000 & 17,2 \\
\hline & 25 & 2,24 & 8,09 & 2805 & 4 & 0,466 & 0,000 & 0,000 & 16,4 \\
\hline \multirow{4}{*}{ NF DK } & 10 & 1,15 & 7,59 & 2380 & 51 & 4,197 & 3,251 & 2,335 & 37,6 \\
\hline & 15 & 1,24 & 7,51 & 2045 & 28 & 1,632 & 1,161 & 0,934 & 40,1 \\
\hline & 20 & 1,34 & 7,46 & 1911 & 83 & 4,896 & 3,483 & 2,569 & 42,4 \\
\hline & 25 & 1,53 & 7,49 & 1559 & 75 & 23,782 & 2,090 & 1,401 & 25,2 \\
\hline \multirow{4}{*}{ NF DL } & 10 & 1,43 & 8,04 & 3025 & 20 & 1,166 & 0,697 & 0,234 & 10,3 \\
\hline & 15 & 1,68 & 8,00 & 2965 & 35 & 2,332 & 1,625 & 0,934 & 18,5 \\
\hline & 20 & 1,94 & 8,03 & 2995 & 28 & 1,865 & 0,929 & 0,467 & 12 \\
\hline & 25 & 1,90 & 7,94 & 2530 & 12 & 0,699 & 0,464 & 0,234 & 6,0 \\
\hline \multirow{4}{*}{ NF TS40 } & 10 & 1,32 & 7,91 & 3425 & 24 & 1,632 & 0,929 & 0,467 & 40 \\
\hline & 15 & 1,51 & 7,91 & 2760 & 28 & 1,632 & 1,161 & 0,701 & 38 \\
\hline & 20 & 1,64 & 7,99 & 2870 & 16 & 0,933 & 0,697 & 0,234 & 30 \\
\hline & 25 & 1,77 & 7,98 & 2865 & 4 & 0,466 & 0,000 & 0,000 & 29 \\
\hline \multirow{4}{*}{ XF NF 45} & 10 & 1,46 & 8,20 & 3540 & 83 & 5,596 & 3,018 & 1,168 & 8,4 \\
\hline & 15 & 1,71 & 8,24 & 3625 & 102 & 9,093 & 3,715 & 1,868 & 46 \\
\hline & 20 & 1,84 & 8,17 & 3460 & 110 & 7,461 & 6,269 & 2,335 & 27 \\
\hline & 25 & 2,12 & 8,27 & 3420 & 114 & 7,694 & 4,179 & 2,102 & 39 \\
\hline
\end{tabular}

\section{4. pH'nın Arıtım Performansına Olan Etkisi}

Şekil 9'da farklı pH'larda yapılan denemelere ait çıkış değerleri görünmektedir. NF270 membranı için pH arttıkça ilekenlikte düşüş gözlenmiş ve pH 3 için $3300 \pm 28,3$ olan iletkenlik pH 10 ile $2630 \pm 28,2$ $\mu \mathrm{S} / \mathrm{cm}$ değerine düşmüştür. Benzer sonuçlar NF90 membranı için de gözlemlenmiştir. Bu membran için pH'nın 3 ten 10'a yükselmesi, iletkenlik değerinde $1261 \pm 1,41$ den $418 \pm 2,82 \mu \mathrm{S} / \mathrm{cm}$ 'ye düşmesine neden olmuştur. Fakat NFTS40 membranı için süzüntü iletkenlik değeri sadece pH 10 değerine yükseltildiğinde düşüşe geçmiştir. İletkenlik seviyesi 3 ve 7 için sırasıyla $3065 \pm 21,21$ ve $3180 \mu \mathrm{S} / \mathrm{cm}$ iken $\mathrm{pH} 10$ için $2390 \pm 70,71 \mu \mathrm{S} / \mathrm{cm}$ 'ye düşmüştür.

Renk giderim verimleri de Şekil 9b'de görülmektedir. Görüleceği üzere, test edilen tüm pH'larda NF90 membranı \%100'lük boya giderimi sağlamıştır. NF270 membranı için ise nötral değer renk giderimine olumsuz bir etki yaratmıştır. $\mathrm{pH} 3$ değeri için \%99'un üzerinde giderim verimi elde edilirken giderim verimi $\mathrm{pH} 7$ için \%92'ye düşmüştür. $\mathrm{pH}$ sonraki süreçte 10 'a yükseltilince giderim verimi \%96,5 olarak tespit edilmiştir. Asidik ya da bazik koşullar NF270 membranı için renk 
gideriminde nötral seviyeler kadar etkin olamamıştır. Muhtemel sebep asidik ya da bazik boyaların uygun $\mathrm{pH}$ 'larda çözünür forma geçmeleridir.

NFTS40 membranında yapılan arıtım atıksuyun pH'sından etkilenmemiştir ve çıkış renk konsantrasyonu yaklaşık 12 Pt-Co'dur. KOİ giderim verimleri ise Şekil 9c'de görünebilmektedir. Test edilen tüm membranlar için farklı $\mathrm{pH}$ 'larda \%90'ın üzerinde KOİ giderim verimi gözlemlenmiştir.

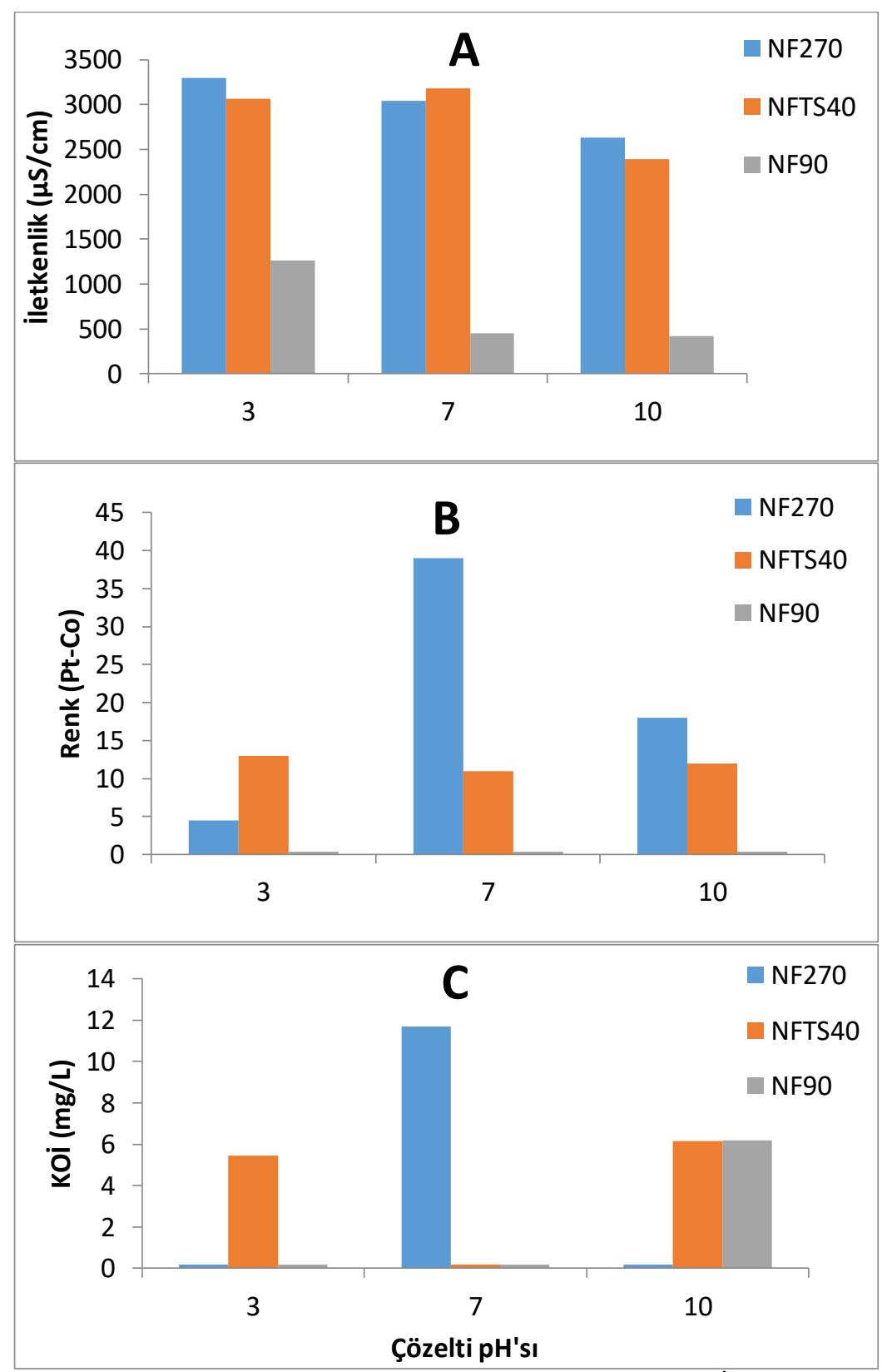

Şekil 9. Farklı pH değerleri için NF270, NF90 ve NFTS40 membranlarında İletkenlik, renk, KOİ giderim verimleri (Giriş iletkenlik: $4515 \mu \mathrm{S} / \mathrm{cm}$; renk: $518 \mathrm{Pt}-\mathrm{Co}$ ve KOİ: $119 \mathrm{mg} / \mathrm{L}$ ).

\section{Sonuç ve Öneriler}

Nanofiltrasyon ve ters ozmoz membranları tekstil endüstrisi atıksuyu için filtrasyon testlerinde kullanılmıştır. Nanofiltrasyon membranları içerisnde NF90 membranı iletkenlik ve KOİ gideriminde en yüksek verimi sergilerken, NFTS40, NFDK, NFDL ve NF270 membranları renk gideriminde etkin iken iletkenlik gideriminde NF90 kadar etkili olamamışlardır. pH'da yapılan değişiklik akı değerlerini etkilemiştir. NF270 membranı için pH'nın 10'a yükseltilmesi, nötral ya da asidik koşullara göre daha yüksek akı/geçirgenlik elde edilmesini sağlamıştır. Ters ozmoz membranları ile yüksek oranlarda renk 
(>\%99), iletkenlik (\%98) ve KOİ (\%97) giderim verimleri elde edilmiştir. Bu çalışma NF90 membranı ile \%99 renk, \%94 iletkenlik ve \%97 oranında KOİ giderimi sağladığını ortaya koymaktadır. Daha yüksek giderim verimleri için ters ozmoz membranları gerekmektedir. Test edilen membranların gerçek ölçekli sistemlere uygulanması için daha uzun süreli testlere ihtiyaç duyulmaktadır. Bu amaçla geri döngülü ya da konsantre modda çalıştırılan çapraz akışlı filtrasyon düzenekleri bulunmaktadır.

\section{Teşekkür}

Bu çalışma 113 Y336 numaralı proje ile TÜBİTAK tarafından desteklenmiştir.

\section{Yazarların Katkısı}

Adem YURTSEVER makaledeki sistemin çalıştırılması, analizlerin yapılması, makalenin yazılması ve yazım kurallarının kontrol edilmesinde katkı sağlamıştır. Deniz UÇAR makaledeki sistemin çalıştırılması, analizlerin yapılması, grafiklerin çizilmesi ve makalenin yazılmasında katkı sağlamıştır. Erkan ŞAHINKAYA 113 Y336 numaralı projenin yürütücüsü olup, konunun belirlenmesi, makalenin yazılması, son kontrollerin yapılması ve yorumların genişletilmesinde katkı sağlamıştır.

\section{Çıkar Çatışması Beyanı}

Yazarlar arasında herhangi bir çıkar çatışması bulunmamaktadır.

\section{Araştırma ve Yayın Etiği Beyanı}

Yapılan çalışmada araştırma ve yayın etiğine uyulmuştur.

\section{Kaynaklar}

[1] Marcucci M., Nosenzo G., Capannelli G., Ciabatti I., Corrieri D., Ciardelli G. 2001. Treatment and reuse of textile effluents based on new ultrafiltration and other membrane technologies. Desalination, 138: 75-82.

[2] Amar N.B., Kechaou N., Palmeri J., Deratani A., Sghaier A. 2009. Comparison of tertiary treatment by nanofiltration and reverse osmosis for water reuse in denim textile industry. $\mathrm{J}$. Hazard. Mater., 170: 111-117.

[3] Yurtsever A., Sahinkaya E., Aktaş Ö., Uçar D., Çınar Ö., Wang Z. 2015. Performances of anaerobic and aerobic membrane bioreactors for the treatment of synthetic textile wastewater. Bioresour. Technol., 192: 564-73.

[4] Asghar A., Raman A.A.A., Daud W.M.A.W. 2015. Advanced oxidation processes for in-situ production of hydrogen peroxide/hydroxyl radical for textile wastewater treatment: a review. J. Clean. Prod., 87: 826-838.

[5] Körbahti B.K., Turan K.M. 2016. Electrochemical Decolorization of Reactive Violet 5 Textile Dye using Pt/Ir Electrodes. J. Turkish Chem. Soc. Sect. A Chem., 3: 229-246.

[6] Sahinkaya E., Yurtsever A., Çınar Ö. 2017. Treatment of textile industry wastewater using dynamic membrane bioreactor: Impact of intermittent aeration on process performance. Sep. Purif. Technol., 174: 445-454.

[7] Ucar D., Armağan B. 2012. The removal of reactive black 5 from aqueous solutions by cotton seed shell. Water Environ. Res., 84: 323-327.

[8] Uçar D. 2014. Adsorption of Remazol Black RL and Reactive Yellow 145 from Aqueous Solutions by Pine Needles. Iran. J. Sci. Technol. Trans. Civ. Eng., 38: 147-155.

[9] Rodrigues C.S.D., Madeira L.M.,. Boaventura R.A.R. 2013. Treatment of textile dye wastewaters using ferrous sulphate in a chemical coagulation/flocculation process. Environ. Technol., 34: 719729.

[10] Van Der Bruggen B., Everaert K., Wilms D., Vandecasteele C. 2001. Application of nanofiltration for removal of pesticides, nitrate and hardness from ground water: Rejection properties and economic evaluation. J. Memb. Sci., 193: 239-248. 
[11] Cheng S., Oatley D.L., Williams P.M., Wright C.J. 2012. Characterisation and application of a novel positively charged nanofiltration membrane for the treatment of textile industry wastewaters. Water Res., 46: 33-42.

[12] Lau W.-J., Ismail A.F.I. 2009. Polymeric nanofiltration membranes for textile dye wastewater treatment: Preparation, performance evaluation, transport modelling, and fouling control - a review. Desalination, 245: 321-348.

[13] Erswell A., Brouckaert C.J., Buckley C.A. 1988. The reuse of reactive dye liquors using charged ultrafiltration membrane technology. Desalination, 70: 157-167.

[14] Avlonitis S.A., Poulios I., Sotiriou D., Pappas M., Moutesidis K. 2008. Simulated cotton dye effluents treatment and reuse by nanofiltration. Desalination, 221: 259-267.

[15] Zahrim A.Y., Tizaoui C., Hilal N. 2011. Coagulation with polymers for nanofiltration pretreatment of highly concentrated dyes: A review. Desalination, 266: 1-16.

[16] APHA. 2005. Standart Methods for the Examination of Water and Wastewater., 21st ed., Washington DC. USA,.

[17] Mukherjee D., Kulkarni A., Gill W.N. 1996. Chemical treatment for improved performance of reverse osmosis membranes. Desalination, 104: 239-249.

[18] Balannec B., Vourch M., Rabiller-Baudry M., Chaufer B. 2005. Comparative study of different nanofiltration and reverse osmosis membranes for dairy effluent treatment by dead-end filtration. Sep. Purif. Technol., 42: 195-200.

[19] Suksaroj C., Heran M., Allegre C., Persin F. 2005. Treatment of textile plant effluent by nanofiltration and/or reverse osmosis for water reuse. Desalination, 178: 333-341. 